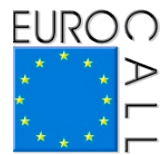

\title{
Exploring collaborative writing in wikis: a genre-based approach
}

\author{
Francesca Coccetta ${ }^{1}$
}

\begin{abstract}
While CALL research into collaborative writing in the L2 using wikis has mainly focused on the texts written by learners in terms of their grammatical accuracy (e.g. Mak \& Coniam, 2008; Lee, 2010), the purpose of the present study is to draw attention to these texts as instances of a given genre. It reports on a small-scale experiment investigating a collaborative writing assignment using wikis focusing on the narrative genre. Specifically, it explores the extent to which firstyear students in the Degree Course in Linguistic and Cultural Mediation at $\mathrm{Ca}$ ' Foscari University of Venice (Italy) used wikis to include hypermedia objects such as audios, videos, images and hyperlinks when engaging with this genre online. The study draws on Systemic Functional Linguistics (Halliday \& Matthiessen, 2004) theory and its extensive research into genre analysis, in particular Hasan's (1984) Generic Structure Potential (henceforth, GSP) and its application to nursery tales.
\end{abstract}

Keywords: wiki, collaborative writing, genre analysis.

\section{Introduction}

The use of wiki for collaborative writing in L2 is nothing new. Several studies have focused mainly on the writing process, demonstrating that, inter alia, from a pedagogical standpoint, wikis promote peer-to-peer interaction (e.g. Bradley, Lindström, \& Rystedt, 2010) and facilitate effective, collaborative language learning (e.g. Oskoz \& Elola, 2010), while from a linguistic perspective they enhance learners' attention to lexicogrammatical form (e.g. Lee, 2010). In particular, wiki texts have been analysed in terms of their lexicogrammatical accuracy (e.g. Mak \& Coniam, 2008), while their compliance with genre conventions has, in comparison, been rather neglected (but see Alyousef \& Picard, 2011; Kuteeva, 2011). Yet the

1. Ca' Foscari University of Venice, Italy; francesca.coccetta@unive.it

How to cite this article: Coccetta, F. (2015). Exploring collaborative writing in wikis: a genre-based approach. In F. Helm, L. Bradley, M. Guarda, \& S. Thouësny (Eds), Critical CALL-Proceedings of the 2015 EUROCALL Conference, Padova, Italy (pp. 133-137). Dublin: Research-publishing.net. http://dx.doi.org/10.14705/rpnet.2015.000322 
affordances provided by wikis as regards well-established genres such as those explored in the studies mentioned above (i.e. stories, brochures and reports) ought, perhaps, to arouse interest among linguists, too.

A wiki is a website where those who use it can add, edit and delete contents in terms of written text, hyperlinks, and multimedia objects such as audios, videos, and images; it also has a page history that keeps a record of all the changes the page has undergone thus allowing users to understand the page's evolution over time. Providing a thorough account of how wikis can reshape existing genres - a book waiting to be written - falls outside the scope of this paper. Rather, in this study, the goal was to measure compliance with and deviation from Hasan's (1984) model of bedtime stories in collaborative wiki writing.

In theory, the reading pathway in a wiki vis-à-vis a book can be affected by the use of hyperlinks: a book's sequential reading convention gives way to multiple readings, as hypertext fiction has shown (Aarseth, 1997). Readers' roles change as they can decide how the story will develop by either clicking or ignoring a link. Moreover, while in children's storybooks illustrations commonly function to "expand, explain, interpret, or decorate a written text" (Bodmer, 1992, p. 72), in wikis they can be used in more creative ways. An example is provided in $\mathrm{Il} \mathrm{racconto}$ a disegni (The tale in drawings) in the Italian children's magazine La Pimpa ${ }^{2}$ where drawings replace carefully-selected nouns (e.g. the noun pappagallina (parrot) in the noun phrase la pappagallina Tita (Tita the parrot)). Finally, audio files can be used in lieu of language for direct speech or provide background music to amuse the readers during the reading.

Using Hasan's (1984) model of nursery tales, this paper reports on an experiment to discover whether the hypermedia affordances provided by wikis engendered compliance or deviance with regard to this model.

\section{Method}

\subsection{Participants}

The experiment involved 55 first-year students in the Degree Course in Linguistic and Cultural Mediation at Ca' Foscari University of Venice attending a 30-hour course on the English verb phrase. The class was divided into 13 groups of four

2. A sample is available at http://www.francopaniniragazzi.it/pimpa/it.fcp.pimpariviste.aprile/disegni.html 
students each and one of three. Each group had a wiki page and a forum they were encouraged to use to swap ideas.

\subsection{Assignment}

The online assignment was designed to foster students' communicative competence (Hymes, 1972) in English, thus complementing the traditional grammar-translation method adopted in class. Each group was asked to write an original bedtime story collaboratively using a wiki. In the instructions, the students were encouraged to use Hasan's (1984) textual model and to add the multimedia resources available through the wiki toolbar (e.g. videos, photos and emoticons) to this language only genre model.

\subsection{Data analysis}

The 14 bedtime stories that were produced were analysed following Hasan's (1984) GSP model which provides the structural elements present in tales, specifies the obligatory and optional ones, and arranges them in order on the basis of their occurrence. The model is shown in Figure 1.

Figure 1. Hasan's (1984) GSP model of nursery tales

\begin{tabular}{|l} 
Legend: \\
$\ldots$
\end{tabular}$\quad \begin{aligned} & \text { obligatory element(s) } \\
& \text { the element on the right of the sign } \\
& \text { cannot precede the one on the left } \\
& \text { the order of the elements is reversible } \\
& \text { elements that cannot be moved }\end{aligned}$

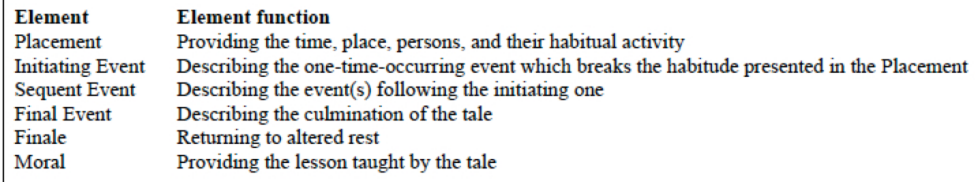

The analysis also took the semiotic resources used in the development of the story and their function into account.

\section{Discussion}

The themes of the 14 stories are run-of-the-mill. For example, they involve stories about beautiful princesses who succeed in not marrying the old man their father 
imposed on them, as well as stories about mistreatment of humanised animals in zoos that in the end are freed. The picture emerging from these stories indicates strong compliance with Hasan's (1984) model and limited use of hypermedia resources. None of the groups included hyperlinks with the result that the story follows the top-bottom, left-right reading pathway typical of the printed page. Similarly, no audios were included. However, two groups included a video taken from YouTube, specifically a video presenting Brahm's lullaby - a favourite among parents. In one case, the video precedes the start of the story and in the other case it comes after the end as if it were a mere adjunct in terms of Hasan's (1984) model. Both these adjuncts are action-oriented: the first invites the reader to play the song as a warm-up and if they let it play, it will accompany the reading; the second invokes the typical action of singing a lullaby that parents undertake once the story they are reading is finished.

As can be inferred from the posts published in the forum, students were particularly sensitive to images: all the groups made use of images, some even drew their own drawings, while others made use of computer graphic software tools - not in the wiki toolbar - to draw them. From a subjective point of view, the degree of image integration varies: while there is general coherence between the details provided in the text and the drawings, some groups using clip arts do not seem to achieve the desired coherence between text and image.

From a more objective standpoint, there is compliance with Hasan's (1984) model as all the obligatory elements are present. A good example is the animal story mentioned above where the animals decide to do something to help a mistreated lion cub (Initiating Event), go to his cage to comfort him, but when the zookeeper discovers them he realises he has been mean to them (Sequent Events) and frees the animals (Final Event). Additionally, many stories included the optional Moral element. The students' forum discussion about whether this was compulsory indicates their interest in genre coherence. Some pleasing creativity vis-à-vis textual structure is evident such as the optional mini-genre (Baldry \& Thibault, 2006) we can call Book Cover consisting of a picture recalling the content of the story, the story's title and the names of the writers occurring at the top of the page. However, none of the students' story significantly modifies the narrative structure outlined in Hasan's (1984) model.

\section{Conclusions}

The affordances provided by wikis to reshape the narrative genre have been partly documented. The experiment reported is an attempt to shift the research focus from lexicogrammatical accuracy to students' awareness and mastery of text and genre 
characteristics. Many aspects of this shift, such as the effects of peer collaboration in the writing process, on the end product warrant further investigation that goes beyond this pilot study.

\section{References}

Aarseth, E. (1997). Cybertext. Baltimore: JHUP.

Alyousef, H. S., \& Picard, M. Y. (2011). Cooperative or collaborative literacy practices: mapping metadiscourse in a business students' wiki group project. AJET, 27(3), 463-480.

Baldry, A., \& Thibault, P. (2006). Multimodal transcription and text analysis. London: Equinox. Bodmer, G. R. (1992). Approaching the illustrated text. In G.E. Sadler (Ed.), Teaching children's literature: issues, pedagogy, resources (pp. 72-79). New York: The Modern Language Association of America.

Bradley, L., Lindström, B., \& Rystedt, H. (2010). Rationalities of collaboration for language learning in a wiki. ReCALL, 22(2), 247-265. doi:10.1017/S0958344010000108

Halliday, M. A. K, \& Matthiessen, C. (2004). An introduction to functional grammar (3rd ed.). London: Arnold.

Hasan, R. (1984). The nursery tale as a genre. Nottingham Linguistic Circular, 13, 71-102.

Hymes, D. H. (1972). On communicative competence. In J. B. Pride \& J. Holmes (Eds.), Sociolinguistics: selected readings (pp. 269-293). Harmondsworth: Penguin.

Kuteeva, M. (2011). Wikis and academic writing: changing the writer-reader relationship. ESP, 30, 44-57. doi:10.1016/j.esp.2010.04.007

Lee, L. (2010). Exploring wiki-mediated collaborative writing: a case study in an elementary Spanish course. CALICO Journal, 27(2), 260-276. doi:10.11139/cj.27.2.260-276

Mak, B., \& Coniam, D. (2008). Using wikis to enhance and develop writing skills among secondary school students in Hong Kong. System, 36, 437-455. doi:10.1016/j.system.2008.02.004

Oskoz, A., \& Elola, I. (2010). Collaborative writing: fostering foreign language and writing conventions development. Language Learning \& Technology, 14(3), 51-71. 


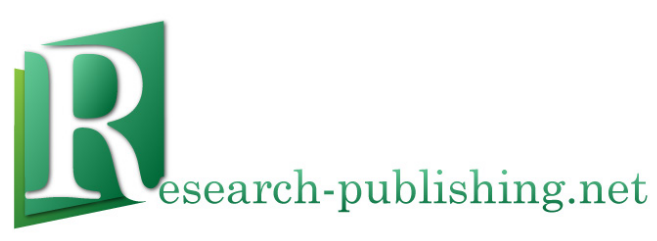

Published by Research-publishing.net, not-for-profit association Dublin, Ireland; info@research-publishing.net

(C) 2015 by Research-publishing.net (collective work)

(C) 2015 by Author (individual work)

Critical CALL - Proceedings of the 2015 EUROCALL Conference, Padova, Italy Edited by Francesca Helm, Linda Bradley, Marta Guarda, and Sylvie Thouësny

Rights: All articles in this collection are published under the Attribution-NonCommercial -NoDerivatives 4.0 International (CC BY-NC-ND 4.0) licence. Under this licence, the contents are freely available online (as PDF files) for anybody to read, download, copy, and redistribute provided that the author(s), editorial team, and publisher are properly cited. Commercial use and derivative works are, however, not permitted.

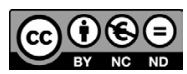

Disclaimer: Research-publishing.net does not take any responsibility for the content of the pages written by the authors of this book. The authors have recognised that the work described was not published before, or that it is not under consideration for publication elsewhere. While the information in this book are believed to be true and accurate on the date of its going to press, neither the editorial team, nor the publisher can accept any legal responsibility for any errors or omissions that may be made. The publisher makes no warranty, expressed or implied, with respect to the material contained herein. While Research-publishing.net is committed to publishing works of integrity, the words are the authors' alone.

Trademark notice: product or corporate names may be trademarks or registered trademarks, and are used only for identification and explanation without intent to infringe.

Copyrighted material: every effort has been made by the editorial team to trace copyright holders and to obtain their permission for the use of copyrighted material in this book. In the event of errors or omissions, please notify the publisher of any corrections that will need to be incorporated in future editions of this book.

Typeset by Research-publishing.net

Fonts used are licensed under a SIL Open Font License

ISBN13: 978-1-908416-28-5 (Paperback - Print on demand, black and white)

Print on demand technology is a high-quality, innovative and ecological printing method; with which the book is never 'out of stock' or 'out of print'.

ISBN13: 978-1-908416-29-2 (Ebook, PDF, colour)

ISBN13: 978-1-908416-30-8 (Ebook, EPUB, colour)

Legal deposit, Ireland: The National Library of Ireland, The Library of Trinity College, The Library of the University of Limerick, The Library of Dublin City University, The Library of NUI Cork, The Library of NUI Maynooth, The Library of University College Dublin, The Library of NUI Galway.

Legal deposit, United Kingdom: The British Library.

British Library Cataloguing-in-Publication Data.

A cataloguing record for this book is available from the British Library.

Legal deposit, France: Bibliothèque Nationale de France - Dépôt légal: décembre 2015. 